The Canadian Mineralogist

Vol. 42, pp. 1315-1329 (2004)

\title{
ANALYSIS OF EVAPORATE MOUNDS AS A COMPLEMENT TO FLUID-INCLUSION THERMOMETRIC DATA: CASE STUDIES FROM GRANITIC ENVIRONMENTS IN NOVA SCOTIA AND PERU
}

\author{
DANIEL J. KONTAK ${ }^{\S}$ \\ Nova Scotia Department of Natural Resources, P.O. Box 698, Halifax, Nova Scotia B3J 2T9, Canada
}

\begin{abstract}
The bulk composition of fluid inclusions is generally determined by using the temperature of ice melting (i.e., freezing-point depression of $\mathrm{H}_{2} \mathrm{O}-\mathrm{NaCl}$ ) and relating this to the ice-melting curve in the two-component system $\mathrm{H}_{2} \mathrm{O}-\mathrm{NaCl}$. In reality, natural systems are more complex. Therefore, the bulk composition is referred to as equivalent wt. $\% \mathrm{NaCl}$ to account for the presence of other, generally undetermined, cations (e.g., $\mathrm{K}, \mathrm{Ca}, \mathrm{Fe}, \mathrm{Mn}, \mathrm{Mg}$ ). Inferences of a more complex chemical composition are generally made on the basis of the depression of the eutectic temperature for the $\mathrm{H}_{2} \mathrm{O}-\mathrm{NaCl}$ system $\left(-21.2^{\circ} \mathrm{C}\right)$, the other common solutes being $\mathrm{CaCl}_{2}, \mathrm{MgCl}_{2}$, and $\mathrm{FeCl}_{2}$. Such an approach is qualitative at best, and the inherent problem of metastability invites caution. An alternative, relatively simple and cost-effective method among the many analytical methods available, is to artificially decrepitate fluid inclusions and analyze the resulting evaporate mounds with an electron microprobe equipped with an imaging system. To illustrate the potential of the method, three granitic environments, in Nova Scotia and in Peru, were chosen, two mineralized ( $\mathrm{Sn}, \mathrm{Cu}, \mathrm{Zn}$ ) and one barren (tourmaline pegmatite). Standard fluid-inclusion thermometric data have been integrated with compositions determined from evaporate mounds in the same suite of samples. The following points emerge: (1) the inclusions are invariably multi-component, being dominated by $\mathrm{Na}-\mathrm{K}-\mathrm{Ca}$, but in consistently different proportion that reflect protracted fluid:rock interaction and mixing of reservoirs; (2) the low first-melting temperatures (i.e., $<-50^{\circ} \mathrm{C}$ ) do not unequivocally indicate the presence of $\mathrm{CaCl}_{2}$ in solution; (3) high concentrations of $\mathrm{Fe}$ and $\mathrm{Mn}$ are common within the mineralized systems examined, in addition to lesser amounts of $\mathrm{Sr}, \mathrm{Ba}, \mathrm{P}$ and $\mathrm{Zn}$, and (4) the two methods complement each other, together providing a much more comprehensive account of the nature of the fluid and its evolution in space and time.
\end{abstract}

Keywords: fluid inclusions, evaporate mounds, granites, pegmatites, tin mineralization. Nova Scotia, Peru.

\section{SOMMAIRE}

La composition globale de la phase fluide piégée dans les cristaux est généralement établie au moyen de la température de fusion de la glace, c'est-à-dire, l'abaissement du point de congélation de l'eutectique du système $\mathrm{H}_{2} \mathrm{O}-\mathrm{NaCl}$, mis en relation avec la courbe décrivant la fusion de la phase solide dans le système binaire $\mathrm{H}_{2} \mathrm{O}-\mathrm{NaCl}$. En fait, les systèmes naturels sont plus complexes. Pour cette raison, la composition globale du fluide est exprimée en termes d'équivalents de $\mathrm{NaCl}$ afin de rendre compte d'autres cations, non déterminés, par exemple $\mathrm{K}, \mathrm{Ca}, \mathrm{Fe}, \mathrm{Mn}, \mathrm{Mg}$. Des conclusions à propos de la composition chimique plus complexe sont généralement faites pour rendre compte de l'abaissement de l'eutectique en dessous de $-21.2^{\circ} \mathrm{C}$, sa valeur dans le système $\mathrm{H}_{2} \mathrm{O}-\mathrm{NaCl}$. Les autres solutés courants sont $\mathrm{CaCl}_{2}, \mathrm{MgCl}_{2}$, et $\mathrm{FeCl}_{2}$. Une telle approche est définitivement qualitative, et le problème de métastabilité mérite une attention particulière. Une alternative relativement simple et peu couteuse, parmi les multiples méthodes analytiques qui sont disponibles, implique la décrépitation artificielle des inclusions fluides afin d'en analyser les amoncellements de matière évaporée avec une microsonde électronique munie d'un analyseur d'images. Afin d'illustrer le potentiel de la méthode, trois milieux granitiques ont été choisis, en Nouvelle-Écosse et au Pérou, deux de ceux-ci étant minéralisés ( $\mathrm{Sn}, \mathrm{Cu}, \mathrm{Zn}$ ) et un étant stérile (pegmatite à tourmaline). La thermométrie standard effectuée sur les inclusions fluides a été intégrée avec les compositions de ces amoncellements produits de la même suite d'échantillons. Il en ressort les points suivants: (1) les inclusions sont invariablement à multi-composantes, avec $\mathrm{Na}-\mathrm{K}-\mathrm{Ca}$ comme cations principaux, mais en proportions variables qui traduisent une longue interaction entre fluide et roche, et un mélange de réservoirs; (2) les faibles températures de fusion initiale $\left(<-50^{\circ} \mathrm{C}\right)$ n'indiquent pas nécessairement la présence de $\mathrm{CaCl}_{2}$ dans le système hydrothermal; (3) des concentrations élevées de Fe et de Mn sont courantes dans les systèmes minéralisés examinés, de même que des quantités moindres de Sr, Ba, P et Zn, et (4) les deux méthodes sont complémentaires, et ensemble contribuent à un meilleur aperçu de la nature de la phase fluide et son évolution dans l'espace et le temps.

(Traduit par la Rédaction)

Mots-clés: inclusions fluides, amoncellements de matière évaporée, granites, pegmatites, minéralisation en étain, Nouvelle-Écosse, Pérou.

$\S \quad$ E-mail address: kontakdj@gov.ns.ca 


\section{INTRODUCTION}

Thermometric analyses of fluid inclusions, in particular temperatures of ice melting, provide a rapid means of obtaining bulk chemical compositions, in particular the frequently referred to wt.\% equiv. $\mathrm{NaCl}$ term (e.g., Crawford 1981, Roedder 1984, Goldstein \& Reynolds 1994, Bodnar \& Vityk 1994). As such, they provide a valuable non-destructive means of estimating fluid composition. However, this method assumes a simple binary system and treats all compositions equally, hence the equivalent wt.\% value (Crawford 1981). More complicated compositions can, however, be determined by using the sequential freezing method (Haynes 1985, Goldstein \& Reynolds 1994), in which hydrates (e.g., hydrohalite, gas clathrates) can be identified and their melting temperatures determined. In these cases, use of the appropriate ternary system will provide an estimate of the bulk composition of the system, as has been demonstrated for the system $\mathrm{H}_{2} \mathrm{O}-\mathrm{NaCl}$ $-\mathrm{CaCl}_{2}$ (Vanko et al. 1988, Oakes et al. 1990) and $\mathrm{H}_{2} \mathrm{O}-$ $\mathrm{NaCl}-\mathrm{MgCl}_{2}$ (Dubois \& Marignac 1997). However, the difficulty of discriminating between low- to moderatesalinity fluids dominated by $\mathrm{NaCl}$ or $\mathrm{KCl}$, as well the difficulty in interpreting the phase changes in complex multicomponent systems, given the problems of metastability (e.g., Samson \& Walker 2000), limits the potential use of eutectic measurements to infer fluid composition. Although a variety of nondestructive and destructive methods are available to determine the major solute composition of single fluid-inclusions, trace and minor elements (e.g., Heinrich et al. 1992, 1999, Audétat et al. 1998), a relatively simple, efficient, and underutilized method is the analysis of fluid-inclusion decrepitate mounds. This approach is tested here in case studies from Nova Scotia and Peru.

\section{BACKGROUND INFORMATION}

The decrepitate method was first discussed and applied by Eadington (1974). It was the work of Haynes et al. (1988) on synthetic fluid inclusions, however, that demonstrated the reliability of this semiquantitative method to obtain cation and anion concentrations of fluid inclusions. Thus, Haynes \& Kesler (1987) successfully applied decrepitate analysis to the study of MVTstyle mineralization in the East Tennessee and Pine Point districts, and recognized the importance of reduced sulfur in these systems. In another study of MVTtype mineralization, Savard \& Chi (1998) used the method to analyze mineralizing fluids in some carbonate-hosted $\mathrm{Zn}-\mathrm{Pb}$ deposits of the Maritimes Basin of Eastern Canada. In yet another successful study, Chryssoulis \& Wilkinson (1983) applied decrepitate analysis to show that quartz megacrysts in mineralized granite of San Luis Potosí, Mexico, contain fluid inclusions with several wt.\% each of $\mathrm{Na}, \mathrm{K}, \mathrm{Ca}, \mathrm{Mn}, \mathrm{Fe}$ and Ag. Finally, Halter et al. (1998) integrated decrepitate analysis with whole-rock chemistry to examine the alteration profile within a mineralized granite from East Kemptville, Nova Scotia. Other studies from a variety of mineralized environments where decrepitate analysis has been integrated with standard thermometric work include pegmatites (Kontak et al. 2001, 2002), basemetal vein-type mineralization (Kontak et al. 1999), greisens and veins in the South Mountain Batholith of Nova Scotia (Carruzzo et al. 2000), and fluorite mineralization hosted by a carbonatite (Palmer \& WilliamsJones 1996).

The present study focuses on an integration of results of analyses of decrepitates with standard thermometric measurements in order to ascertain the nature of the cation proportions in fluids in a variety of granitic settings. These examples include greisen-type $\mathrm{Sn}$ - basemetal mineralization at East Kemptville, Nova Scotia, a pegmatite-aplite system in the South Mountain Batholith, Nova Scotia, and the San Rafael tin - base metal system of veins in southeastern Peru (Fig. 1). The results of this study confirm those of previous investigators and indicate that this rapid, relatively simple technique provides informative data that complement standard thermometric work. In addition, the results suggest a distinct fluid composition for mineralized versus barren systems in granitic environments that may have implications for exploration. Recently Roedder \& Bodnar (1997) suggested that this method be referred to as evaporate analysis to distinguish it from nebulizate analysis, both of which require decrepitation of the fluid inclusion. This change in nomenclature is adopted herein.

\section{ENVIRONMENTS STUDIED}

\section{Peggys Cove, Nova Scotia}

Flat-lying, layered pegmatite-aplite sheets occur within a biotite-muscovite leucomonzogranite of the Halifax pluton, part of the large, peraluminous South Mountain Batholith (SMB) of southern Nova Scotia (Figs. 1a, b). The similar ages of $c a .370 \mathrm{Ma}$ for both host rock and the aplite-pegmatite sheets suggest a close petrogenetic association of the two granitic lithologies. Offshore from the coastal outcrops are metaturbiditic country-rocks of the Lower Paleozoic Meguma Group (MacDonald \& Horne 1988), and this material accounts for the abundant xenoliths observed in the leucomonzogranite host. The pegmatite-aplite sheets are zoned, with a basal aplite, commonly with line-rock texture, that is overlain by coarse pegmatite with combtextured K-feldspar. The boundary layer between these two zones is generally defined by coarse, intergrown quartz - K-feldspar - muscovite - tourmaline pegmatite with pocket zones. A detailed petrological and stable-isotope study of these rocks (Kontak et al. 2002) suggests an origin for the pegmatites involving local generation of volatile-rich melt via interaction of the 

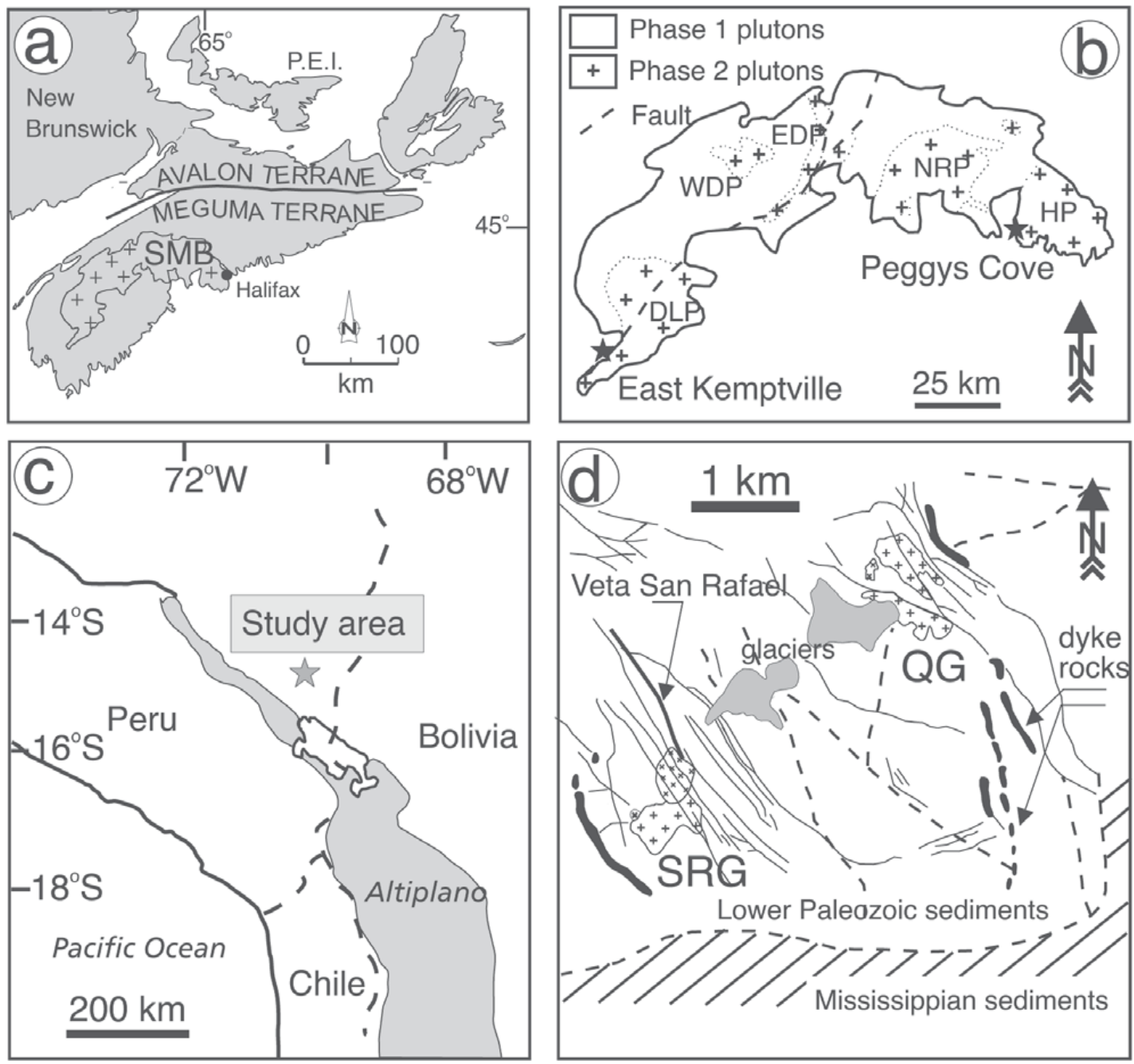

Fig. 1. Location maps for the various areas studied. (a) Outline of Maritime Canada with location of the South Mountain Batholith (SMB) within the Meguma Terrane of southern Nova Scotia. (b) Outline of the SMB showing the distribution of early phase 1 and late phase 2 intrusions, and location of the two study areas, namely Peggys Cove (pegmatite-aplite sheets) and East Kemptville ( $\mathrm{Sn}-\mathrm{Cu}-\mathrm{Zn}-\mathrm{Ag}$ deposit). (c) Outline of the cental Andes showing location of San Rafael study area in southeastern Peru. (d) Simplified geology of San Rafael showing outline of the San Rafael (SRG) and Quenamari (QG) granites. Samples for the study come from within the SRG, both close to and away from mineralized veins (e.g., Veta San Rafael).

xenoliths and magma, rather than formation from extreme fractional crystallization of a progenitor melt. Samples of the pegmatite, including the pocket zones, were used for the fluid-inclusion study.

East Kemptville, Nova Scotia (Sn-Cu-Zn-Ag deposit)

At the East Kemptville tin deposit, the host rock topaz-muscovite leucogranite represents the end product of protracted crystal-fluid fractionation of the Davis Lake pluton (Dostal \& Chatterjee 1995), itself part of the large, peraluminous 370 Ma South Mountain Batholith of southern Nova Scotia (Fig. 1b). The deposit occurs at the contact between the leucogranite and metaturbidites of the Meguma Group. The upper contact of the leucogranite is marked by a chilled zoned with bodies of layered aplite-pegmatite containing unidirectional solidification textures (UST). Mineralization 
consists of cassiterite-bearing pegmatites, quartz - topaz - cassiterite - sulfide greisens (i.e., main mineralization), and quartz-sulfide veins (Kontak 1994, Halter et al. 1996). Similar ages and isotopic signatures indicate that this mineralization represents a single magmatic-hydrothermal event, and there is little evidence for incursion of another fluid or significant interaction of the mineralizing fluid with an exotic reservoir (Kontak 1994). Samples used in this study were collected from altered leucogranite, pegmatite, greisen and sulfide veins.

\section{San Rafael, southeastern Peru (Sn-Cu deposit)}

In southeastern Peru, that part lying at the northern termination of the Central Andean tin belt, a $25 \mathrm{Ma}$, high-level, biotite-cordierite monzogranite stock intruding Lower Paleozoic metasandstones and metasiltstones of the Sandia Formation contains a high-grade lode-tin deposit ( $c a$. 36,685 t tin concentrate produced in 2000; Clark et al. 2000, Kontak \& Clark 2002) (Figs. 1c, d). The mineralization occurs as vertically zoned (i.e., $\mathrm{Cu}: \mathrm{Sn}$ ratio decreases with depth), high-grade $\mathrm{Sn}-\mathrm{Cu}$ chloritic lodes containing coarse cassiterite and chalcopyrite (Palma \& Clark 1982). Within the granite occurs a pervasive, albeit cryptic, metasomatism reflecting widespread infiltration of a dominantly magma-derived, high-temperature (to $c a .550^{\circ} \mathrm{C}$ ) brine, but mixing of this fluid with a low-salinity, probably meteoric fluid occurred (Kontak \& Clark 2002). The metasomatic overprint is reflected by the presence of: (1) secondary, end-member albite and K-feldspar, (2) fluid-mediated ordering of originally disordered $\mathrm{Al}$ and $\mathrm{Si}$ in the alkali feldspar megacrysts (Kontak et al. 1984), and (3), most relevant to this study, abundant secondary fluid-inclusions in the quartz megacrysts. Samples of the metasomatized San Rafael granite were used for the present fluid-inclusion study.

\section{Analytical TechniQues}

Samples used in this study formed part of previous petrological studies that documented the nature of mineralization, alteration and fluid composition in the areas of interest. Details of the thermometric work on these suites have been presented elsewhere. The reader is referred to these sources for more detailed descriptions of the fluid inclusions, phase behavior during cooling and heating runs, and results of thermometric measurements (Kontak et al. 2001, 2002, Kontak \& Clark 2002).

Evaporate mounds were prepared in the following manner. (1) Chips of material used for fluid-inclusion thermometry were inserted into the same heating-cooling chamber previously used, i.e., in this case a USGStype gas-flow heating-freezing stage. (2) Samples were rapidly heated to artificially induce decrepitation, this generally occurring in the range $350-550^{\circ} \mathrm{C}$, as samples dictated. (3) Samples were subsequently quenched by immediately turning off the power supply to the heating stage. (4) Chips were transferred onto a glass slide and examined in reflected light microscopy to ensure that sufficient decrepitation of fluid inclusions had occurred. The presence of evaporate mounds is readily observable, as the surface of samples is generally covered with circular mound features, typically surrounded by an annulus of smaller debris (Figs. 2a, b). As noted below, where very-low-salinity inclusions are present (i.e., $\leq 0.5$ wt.\% equiv. $\mathrm{NaCl}$ ), mounds may not form. Instead, open inclusions without decrepitates will be observed. (5) The chip was then transferred to double-sided carbon tape attached to a petrographic glass slide (Fig. 3c) suitable for loading onto a mount for insertion into the electronmicroprobe chamber, subsequent to the necessary coating with carbon. An important modification of this technique that others might consider where appropriate is to insert under the fluid-inclusion chip a silica plate, and decrepitate onto this substrate. This modification will permit analysis of a Ca-rich fluid inclusion hosted by, for example, a Ca-rich phase such as fluorite, which was done by Palmer \& Williams-Jones (1996).

Imaging and analysis of carbon-coated mounds were done using a JEOL 733 Superprobe with a LINK EXL energy-dispersion system (EDS) system located in the Department of Earth Sciences, Dalhousie University, Halifax, Nova Scotia. Evaporate mounds were located using back-scattered (BSE) and secondary electron imaging (SEI). The analyses were done using the following operating conditions: $3-40 \mu \mathrm{m}$ beam or rastering, accelerating voltage $15 \mathrm{kV}$, current $10 \mathrm{nA}$, and counting time 40 seconds. Other investigators have used an SEM setup with an EDS analyzing system (e.g., Halter et al. 1998, Savard \& Chi 1998).

For particular mounds, several analyses are made to ensure homogeneity. Where a large evaporate mound is present, either a defocused beam of electrons or a rastering technique is employed to prevent volatilization of light elements and also to provide a more homogeneous sampling size. If a complex composition is present, involving, for example, $\mathrm{Fe}, \mathrm{Mn}$ and $\mathrm{Mg}$, in addition to $\mathrm{Na}, \mathrm{K}$ and $\mathrm{Ca}$, then $\mathrm{BSE}$ imaging provides an indication of the homogeneity of the mounds, as discussed below. In general, however, similar compositions occur within mound groupings, and similar results are obtained regardless of beam size or point versus raster analysis, although exceptions do occur, as noted.

The initial dataset is screened for internal consistency by using the charge balance, the totals and homogeneity of results, as discussed above, to assess the reliability of the analysis. Since the power of this technique is its semiquantitative aspect, the screening need not be as rigorous as for chemical analysis of minerals. Thus, charge balance of $\pm 10-15 \%$ and totals of $95 \pm 10$ wt. $\%$ are general guidelines that are employed. In general, these guidelines are considered flexible and can be modified for specific studies. As the results below indicate, the differences in the decrepitate compositions are 

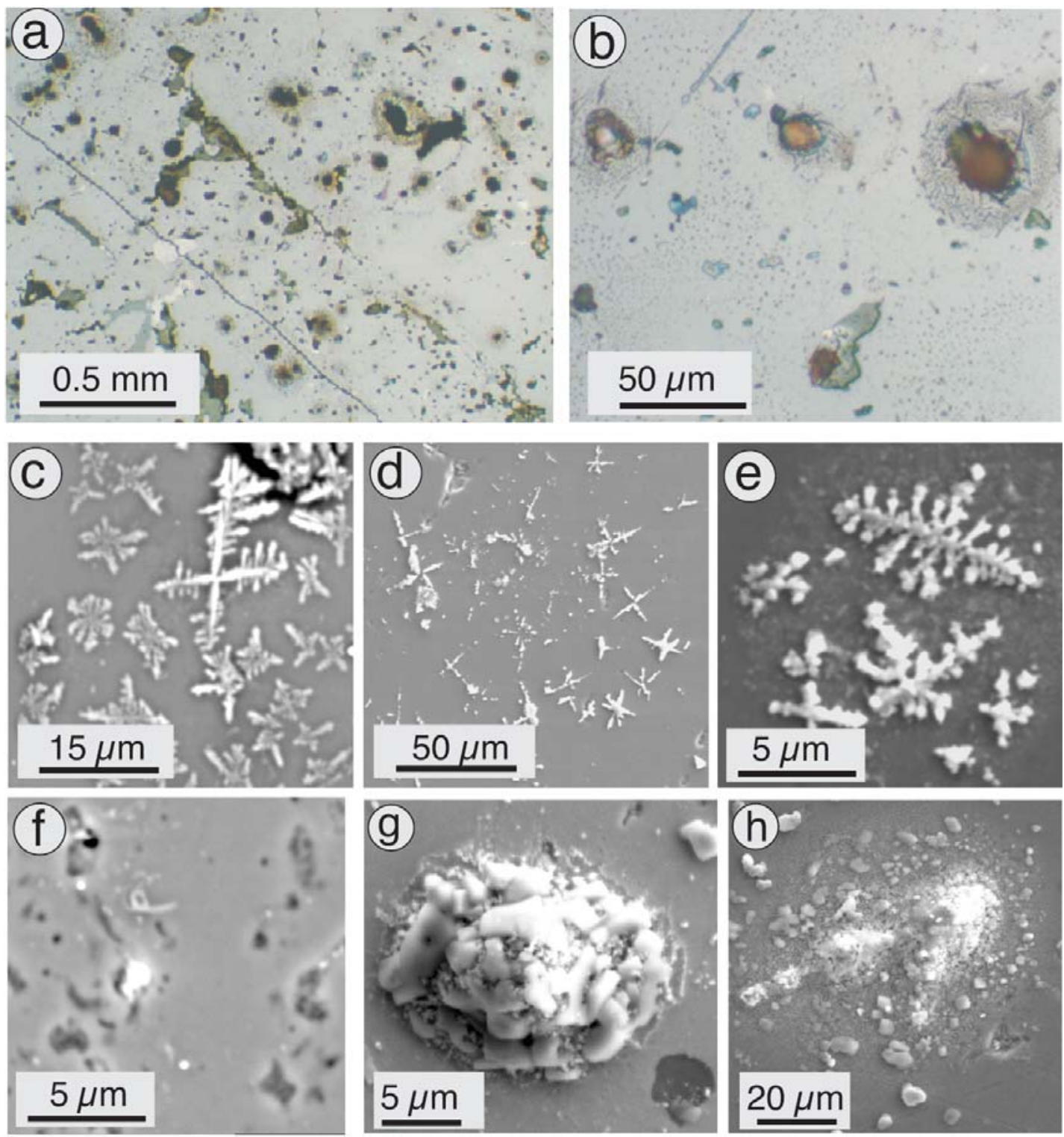

FIG. 2. Photomicrographs of decrepitate mounds. (a) Reflected-light photomicrograph of decrepitate mounds on cassiterite substrate from East Kemptville tin - base-metal deposit, Nova Scotia. (b) Closeup of photo in 2a showing details of mounds. Note the regular round to subrounded outlines and annular array of decrepitate debris (i.e., mound on the right side). (c) Backscattered electron (BSE) image of K-rich mounds on quartz substrate. Sample is of vein quartz hosting base- and preciousmetal mineralization from the Dunbrack vein deposit, Nova Scotia (Kontak et al. 1999). (d) BSE image of K-rich mounds on quartz substrate. Sample is of vein quartz from the Black Bull silica-clay deposit (Kontak \& Kyser 2001) in the Davis Lake pluton of the SMB (Fig. 1b). (e) BSE image of Ca-rich mound on quartz substrate. The sample comes from an auriferous gold vein of the Caribou deposit, Nova Scotia. (f) BSE image of empty vugs (i.e., evacuated fluid-inclusions) in quartz from the Dunbrack base- and precious-metal vein-type deposit, Nova Scotia. (g) BSE image of mixed Na-K mound on cassiterite substrate showing euhedra formed from recrystallized salt halides. Cassiterite-bearing pegmatite, East Kemptville tin deposit, Nova Scotia. (h) BSE image of decrepitate debris on quartz substrate from cassiterite-bearing pegmatite, East Kemptville tin deposit, Nova Scotia. Note that there is an asymmetrical distribution of mounds reflecting egression from a point to the upper right. The difference in brightness of the mound relates to higher concentrations of Fe and $\mathrm{Mn}$ in the upper right versus $\mathrm{Na}$ and $\mathrm{K}$ in the left part of image. 
quite dramatic, and will be obvious even with less stringent guidelines.

Some comments regarding the application of this technique are also considered appropriate here. The modern use of digital imagery makes this technique even more applicable to fluid-inclusion studies. The author, therefore, emphasizes the following points for those interested in integrating this work into their fluidinclusion studies. The initial step is to image the fluidinclusion section to be studied (Fig. 3a), and map out the areas of potential use for thermometry, that is, areas of fluid inclusions with similar proportions of phases [i.e., fluid-inclusion assemblages (FIAs) of Goldstein \& Reynolds 1994]. By using digital images of planes of fluid inclusions (e.g., Fig. 3b) and nearby marks that are easily located, it is possible to follow up on thermometric work with analyses of evaporate mounds of the same FIAs since the chip used can be subsequently mounted on double-side carbon tape and used for imaging and electron-microprobe analysis. Thus, a one-to-one correlation of compositions inferred from thermometry and decrepitate procedure is achievable. Although this was not done for the suite of samples discussed herein, such a procedure is currently being applied where suitable populations of fluid inclusions are present.

\section{Analytical Results: General Considerations}

Before discussing the analytical results for individual study-areas, a few comments on the nature of the evaporate mounds based on the imaging and analyses of numerous mounds in a variety of mineralized environments are considered appropriate, as they may prove beneficial for subsequent investigators. Firstly, the textures of mounds are commonly, but not invariably, a reflection of their makeup, that is whether they are crystalline versus massive (Fig. $2 \mathrm{~g}$ versus $\mathrm{h}$ ). However, it is noted that these observations are not cast in stone and are offered as guidelines only. For example, the more irregular the shape of the mound, the more likely it is to be enriched in one or more of Fe, Mg and Mn (Fig. 2h). In contrast, the more regular the shape, the more likely the mounds are to be dominated by, if not solely composed of, Na or K chlorides, or both (Fig. 2g). Where the mounds are composed solely of Ca chloride, a millipede-type shape is commonly observed (Fig. 2e), and a dendritic pattern with a cross shape usually signifies K-chloride-dominated mounds (Figs. 2c, d).

Secondly, where complex compositions occur, i.e., those containing $\mathrm{Fe}, \mathrm{Mg}, \mathrm{Mn}$ in addition to $\mathrm{Na}, \mathrm{K}$ and $\mathrm{Ca}$, the mounds may be zoned, with the ferromagnesian elements concentrated near the exit point and the alkalis enriched away from there. In this particular study, such inclusions were encountered for some of the East Kemptville (Fig. 2h) and San Rafael samples, as discussed in more detail below.

As a final point worth noting, inclusions containing very-low-salinity fluids may be identified by the ab- sence of mounds. For example, abundant empty cavities were noted in quartz (Fig. 2f) from a base- and precious-metal rich vein deposit in the Musquodoboit Batholith, Nova Scotia; these correlate with a population of low-salinity inclusions based on earlier thermometric studies (Kontak et al. 1999). Similar results have been obtained for quartz-hosted fluid inclusions from a hydrothermal silica-clay deposit within a fault zone along the southern margin of the Davis Lake pluton (Fig. 1b; Kontak \& Kyser 2001, 2002).

In the ensuing discussion of analytical data, results of the decrepitate analyses are interpreted in the context of the thermometric measurements of fluid inclusions for each of the study areas. The results are then discussed collectively.

The Peggys Cove

Tourmaline-Bearing Pegmatites, Nova Scotia

\section{Fluid-inclusion studies}

The types of fluid inclusions observed in quartz from pegmatites in the aplite-pegmatite sheets, including the pocket zones, include liquid (L) - vapor $(\mathrm{V})$ - halite ( $\mathrm{Hl}$ ) and $\mathrm{L}-\mathrm{V}$, but cooling runs indicate that the $\mathrm{L}-\mathrm{V}$ population can be subdivided into aqueous and aqueous-carbonic types. In all cases, consistent proportions of phases indicate that a fluid inclusion assemblage (FIA) was being studied. The aqueous types are interpreted to be exsolved magmatic brine, whereas the carbonic type relate to the influx of exocontact fluids derived from metasedimentary rocks of the Meguma Group (Kontak et al. 2002). The results of low-temperature measurements (i.e., freezing runs) indicate the following important compositional features about the inclusions. (1) A large range in temperatures of first melting $\left(\mathrm{T}_{\mathrm{fm}}\right)$, with two broad peaks at $-60^{\circ}$ and $-50^{\circ} \mathrm{C}$ (Fig. 4a), which suggests that cations in addition to $\mathrm{Na}$ and $\mathrm{K}$ are present in the fluid. (2) Because both hydrohalite and ice melting could be observed in many of the $\mathrm{L}-\mathrm{V}$-type inclusions, the data could be projected into the $\mathrm{NaCl}-\mathrm{CaCl}_{2}-\mathrm{H}_{2} \mathrm{O}$ ternary system (Fig. 4b; note that data for $\mathrm{L}-\mathrm{V}-\mathrm{Hl}$ type inclusions are not plotted). This latter diagram indicates the presence of three compositional groups of fluid inclusions: (i) a $\mathrm{Na}$ fluid, (ii) a Na-Ca fluid, and (iii) a Ca-rich fluid. However, it is possible that additional cations (e.g., $\mathrm{K}, \mathrm{Fe}, \mathrm{Mg}, \mathrm{Mn}$, etc.) exist within each of these types of inclusion, since the diagram is only appropriate for estimation of bulk compositions in the $\mathrm{NaCl}-\mathrm{CaCl}_{2}-\mathrm{H}_{2} \mathrm{O}$ ternary system. Note also that these three different populations of inclusions could not be recognized petrographically.

\section{Compositions of evaporate mounds}

The two samples used for decrepitation are from a layered aplite-pegmatite zone (PCG-99-22) and the pocket zone of a pegmatite sheet (PCG-99-21a). The 
analyses of these two samples indicate that the evaporate mounds consist solely of $\mathrm{Na}, \mathrm{K}$ and $\mathrm{Ca}$ chlorides. These data are summarized in a $\mathrm{Ca}-\mathrm{Na}-\mathrm{K}$ plot in Figure 5. The notable features of the data follow: (1) three distinct populations are indicated, these being $\mathrm{K}-\mathrm{Na}$ rich, $\mathrm{Na}-\mathrm{Ca}$-rich, and $\mathrm{Ca}$-rich (the three populations are shown in the inset in Fig. 5a); (2) an apparent lack of Krich in mounds of sample PCG-99-21a, but with a Carich population, and (3) low totals are recorded for the $\mathrm{Ca}$-rich mounds, i.e., there is insufficient $\mathrm{Cl}$ to provide charge balance, and in some cases sulfur is detected in these same mounds. Although Haynes et al. (1988) noted that variable volatility may occur at excessive temperatures (i.e., above $450^{\circ} \mathrm{C}$ ) and that preferential loss of chlorine and some alkalis may occur, this explanation is not considered appropriate, since the sample was not subjected to such high temperatures, and the $\mathrm{Na}-\mathrm{K}$ mounds did not have this problem.
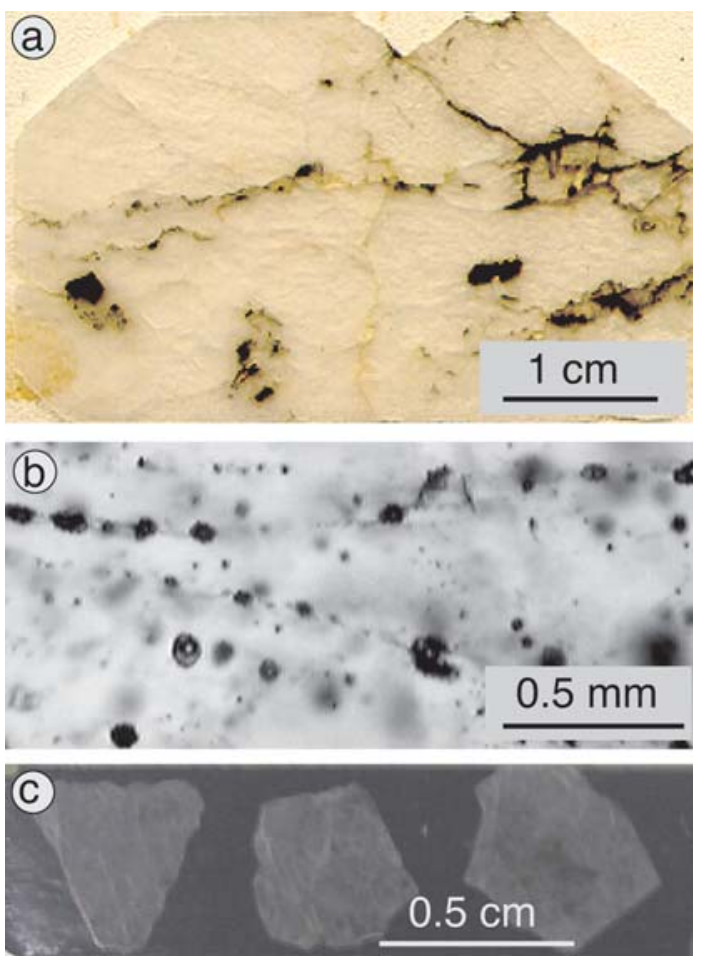

FIG. 3. (a) Fluid-inclusion chip of auriferous quartz-vein material from Meguma gold deposit, Nova Scotia. (b) Photomicrograph of fluid-inclusion plane in quartz chip of Figure 3a. (c) Small fluid-inclusion chips mounted on double sided carbon tape adhered to petrographic slide. The sample is ready for carbon coating and analysis with an electron microprobe.

\section{Comparison of decrepitate and thermometric data}

A comparison of compositions of evaporate mounds and thermometric measurements indicate the following: (1) the mound compositions confirm the three compositional groups in terms of the proportions of $\mathrm{Na}-\mathrm{K}-$ $\mathrm{Ca}$; there is a correlation of the groupings I, II and III in Figure $4 \mathrm{~b}$ versus the inset in Figure 5a. Whereas the thermometric data indicate three distinct compositions, it is the results of mound analyses that discriminate the true composition. (2) The K-deficient nature of the evaporate mounds in sample PCG-99-21a could not be determined on the basis of thermometric measurements alone given the difficulty of discriminating between binary and ternary eutectics with $\mathrm{KCl}, \mathrm{NaCl}, \mathrm{CaCl}_{2}$ and $\mathrm{H}_{2} \mathrm{O}$ (Hall et al. 1988, Oakes et al. 1990). This is an important observation; it suggests that there may be a petrogenetic relationship between the composition of the mounds and the fluid evolution of the aplite-pegmatite system. (3) The Ca-signature, along with trace amounts of $\mathrm{S}$, reflect the incursion of an exotic fluid that may have equilibrated with an external reservoir, as discussed in detail by Kontak et al. (2002). These data support the interpretation that the carbonic component of the fluid also originated from equilibration of a fluid with the metasedimentary rocks of the Meguma Group (Kontak et al. 2002). (4) The eutectic measurements below $-50^{\circ} \mathrm{C}$ (Fig. 4a) must relate to metastability or a recrystallization phenomenon $(c f$. Samson \& Walker 2000), as such low eutectic temperatures cannot be explained by the cation proportions of these inclusions and known phase-relations.

\section{The East Kemptville $\mathrm{SN}_{\mathrm{N}} \mathrm{Z}-\mathrm{Cu}-\mathrm{Ag}_{\mathrm{g}}$ Deposit, Nova Scotia}

\section{Fluid-inclusion studies}

Petrographic observations of the fluid inclusions in altered granite, pegmatites, greisens and veins indicate the following types of inclusions: (1) L-V-Hl-sylvite (Slv), (2) L-V-Hl, and (3) L-V. In addition, a solid phase considered to be a chloride of $\mathrm{Fe}$ has been noted in fluid inclusions in the greisens (Halter et al. 1998). The inclusions are well preserved and uniform proportions of phases occur; FIAs are thus easily identified. During freezing runs, hydrohalite is commonly the last phase to melt in $\mathrm{L}-\mathrm{V}$ inclusions, which indicates compositions of 23-36 wt.\% equiv. $\mathrm{NaCl}$, whereas higher salinities are indicated from the melting of halite and sylvite (to 45 wt. $\%$ equiv. $\mathrm{NaCl}$ ). The $\mathrm{T}_{\text {fm }}$ values cover a broad range from $-70^{\circ}$ to $-20^{\circ} \mathrm{C}$, but most of the data are in the range $-40^{\circ}$ to $-25^{\circ} \mathrm{C}$ (Fig. 6). From the foregoing observations and temperature of last melting of ice and halides, the bulk composition of the fluid is inferred to be 20-45 wt.\% equiv. $\mathrm{NaCl}$. However, from the $\mathrm{T}_{\mathrm{fm}}$ and presence of daughter minerals, the solute 
composition is clearly variable and appears to contain $\mathrm{Na}, \mathrm{K}, \mathrm{Fe}$ and $\mathrm{Mg}$, with lesser $\mathrm{Ca}$, although the relative dominance of these cations is not constrained. On the basis of the homogenization temperatures, these fluids seem dominantly of magmatic nature, and were exsolved from a F-rich granitic melt at $\leq 550-600^{\circ} \mathrm{C}$ (Kontak et al. 2001).

\section{Compositions of evaporate mounds}

Compositions of evaporate mounds (Figs. 2g, h) were obtained for inclusions hosted by quartz and cassiterite from two pegmatites, quartz from a cassiteritebearing miarolitic cavity, and quartz in a sulfide vein. The data indicate that the common cations, in descending order, are $\mathrm{Na}, \mathrm{K}, \mathrm{Fe}, \mathrm{Mn}, \mathrm{Ca}, \mathrm{Sr}$ and $\mathrm{Ba} ; \mathrm{Zn}$ and $\mathrm{P}$, in minor proportions, were mainly detected in the vein sample. The dominant anion is $\mathrm{Cl}$, but minor sulfur occurs in the sulfide vein sample. Although discrete halite and sylvite occur in the evaporate mounds, most analyses indicate mixtures of $\mathrm{Na}-\mathrm{K}-\mathrm{Fe}-\mathrm{Mn}-\mathrm{Ca}$ salts. The most striking feature of the mounds at East Kemptville is the abundance of cations other than $\mathrm{Na}$ and $\mathrm{K}$, in particular those elements that would otherwise go undetec- ted (i.e., $\mathrm{Fe}, \mathrm{Mn}, \mathrm{Ca}, \mathrm{Sr}$ ). These results agree with compositions of evaporate mounds and of fluid-inclusion leachate in samples of greisen and granite from East Kemptville by Halter et al. (1998). Finally, a most important observation is that the elevated Fe and Mn contents obtained for cassiterite-hosted decrepitate mounds are not related to the substrate for the following reasons: (1) the cassiterite is not enriched in either of these elements, and (2) similar results are obtained where quartz is the substrate.

In Figure 7, the $\mathrm{Na}-\mathrm{K}-\mathrm{Ca}$ data are subdivided on the basis of occurrence. The following points are noted: (1) The altered granite is dominated by $\mathrm{Na}$ and $\mathrm{K}$, with very minor $\mathrm{Ca}$. (2) The pegmatite contains two trends, one a $\mathrm{Na}-\mathrm{K}$ and the other a Na-Ca trend, which is similar to the pattern observed at Peggys Cove (Fig. 5). (3) The quartz vein sample contains three distinct populations: (i) a Na-rich fluid, (ii) a mixed fluid of similar proportions of $\mathrm{Ca}-\mathrm{Na}-\mathrm{K}$, and (iii) a Ca-rich fluid. The results for the different samples are plotted together in Figure 8, where the relative enrichment of several cations are examined. From these plots, one sees that: (1) the Na-rich fluid is preferentially enriched in Fe, Mn, and $\mathrm{Sr}$ compared to the K-bearing fluid, and (2) the fluid is depleted in $\mathrm{Mg}$.
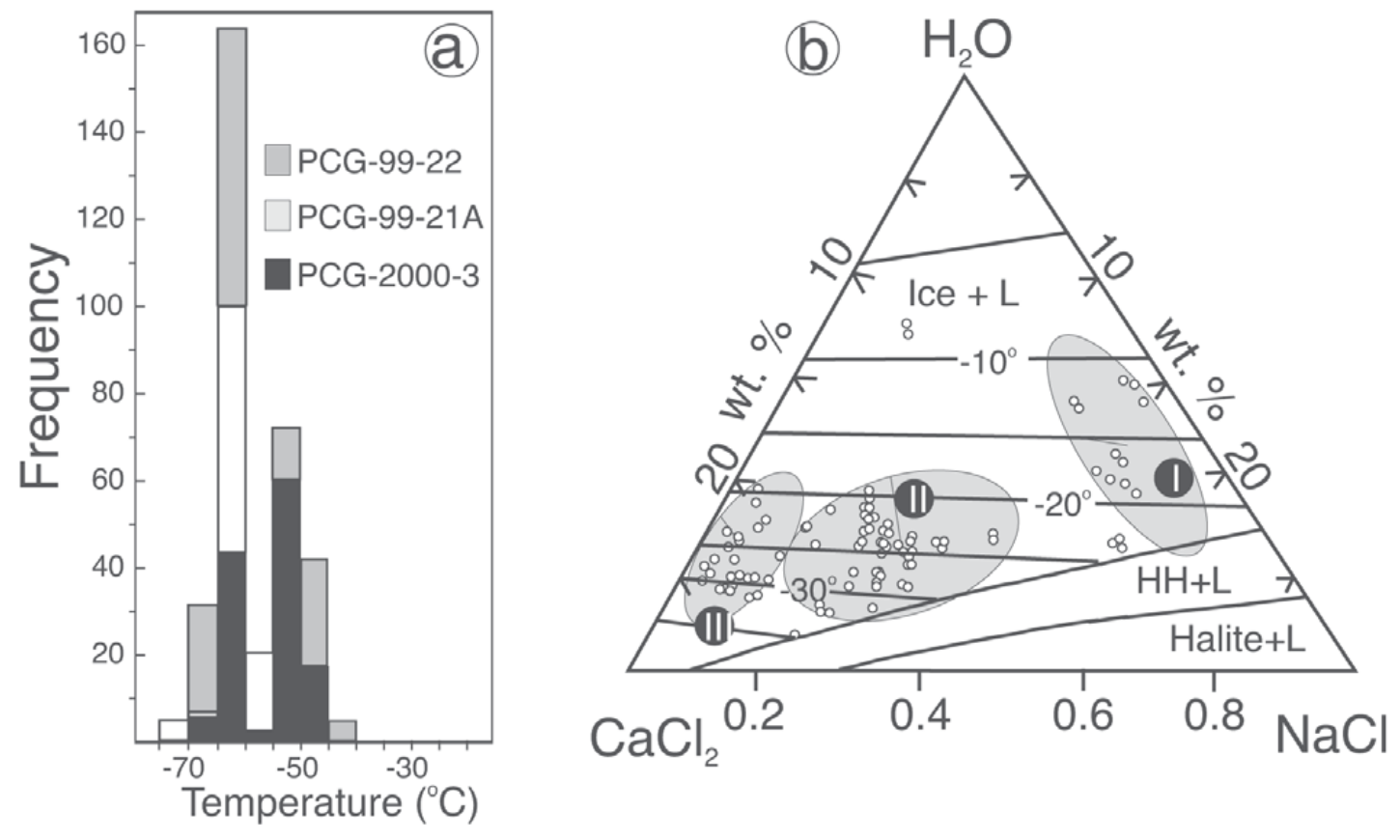

FIG. 4. Thermometric data for quartz-hosted fluid inclusions from layered aplite-pegmatite sheets, Peggys Cove, Nova Scotia (from Kontak et al. 2002). (a) Histogram plot of temperatures of first melting for quartz-hosted inclusions in three samples. (b) Partial phase diagram for the ternary system $\mathrm{CaCl}_{2}-\mathrm{H}_{2} \mathrm{O}-\mathrm{NaCl}$ (after Vanko et al. 1988) showing bulk compositions for fluid inclusions based on hydrohalite-ice melting relationships. 


\section{Comparison of decrepitate and thermometric data}

The low temperatures of first melting, along with the presence of both halite and sylvite in the fluid inclusions of samples from East Kemptville, indicate that the composition of the system is complex. The low $\mathrm{T}_{\mathrm{fm}}$ measurements indicate the presence of cations other than $\mathrm{Na}$ (i.e., $\mathrm{Ca}, \mathrm{Fe}, \mathrm{Mg}$; Borisenko 1977, Vanko et al. 1988 , Dubois \& Marignac 1997). The mound data confirm that a complex, multicomponent system exists and, furthermore, they provide important information regard-
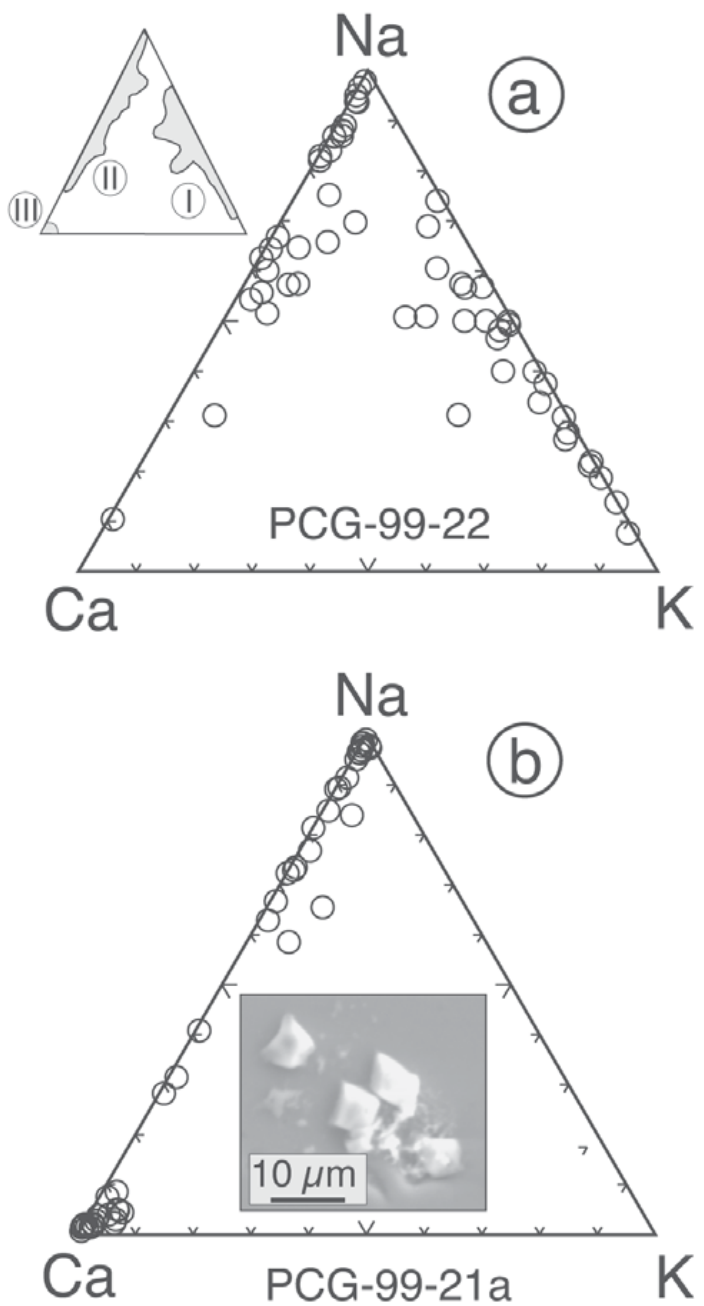

FIG. 5. Plots showing compositions of decrepitate mounds in pegmatitic quartz from aplite-pegmatite sheets, Peggys Cove, Nova Scotia, in Na-K-Ca space. (a) Sample PCG99-22 is from a layered aplite. (b) Sample PCG-99-21 is from a coarse pocket of quartz - muscovite - tourmaline $\mathrm{K}$-feldspar. Inset is BSE image of typical Na-rich mound on quartz substrate from this sample. ing the relative abundance of the components that could not be ascertained from the thermometric measurements. These results also indicate that $\mathrm{Mg}$ is absent in the fluid, although the temperatures of first melting might suggest its presence; instead, Fe chloride is evidently responsible for the low $\mathrm{T}_{\mathrm{fm}}$ measurements in the $-35^{\circ}$ to $-40^{\circ} \mathrm{C}$ range. The apparent enrichment of both of $\mathrm{Fe}$ and $\mathrm{Mn}$ in the fluids and their clear affinity for Na-rich versus K-rich fluids could not be determined with standard thermometric work.

\section{San Rafael Sn-Cu Deposit, Southeastern Peru}

\section{Fluid-inclusion studies}

The secondary fluid-inclusions in the magmatic quartz include the following types: $\mathrm{L}-\mathrm{V}-\mathrm{Hl}-\mathrm{Slv}, \mathrm{L}-\mathrm{V}-$ $\mathrm{Hl}, \mathrm{L}-\mathrm{V}$ and $\mathrm{V}$; a rare $\mathrm{Fe}$ chloride phase, confirmed from SEM analysis, occurs in some inclusions. The large range in $\mathrm{T}_{\mathrm{fm}}$, from $-70^{\circ}$ to near $0^{\circ} \mathrm{C}$ (Fig. 9a), indicates a complex composition of the fluid, with $\mathrm{Ca}, \mathrm{Mg}$ and $\mathrm{Fe}$ probably present in addition to $\mathrm{Na}$ and K. Salinity, determined from dissolution of halite and sylvite, along with ice melting, cover a continuum from $c a$. 65 to 0 wt.\% equiv. $\mathrm{NaCl}$ (Fig. 9b), generally commensurate with decreasing temperature. The range in salinity has been interpreted to reflect the incursion and mixing of meteoric water with a magma-derived brine from a felsic magmatic system undergoing intermittent boiling (Kontak \& Clark 2002). A similar evolution of the fluid phase is recorded by fluid inclusions hosted by vein quartz and cassiterite (Palma \& Clark 1982).

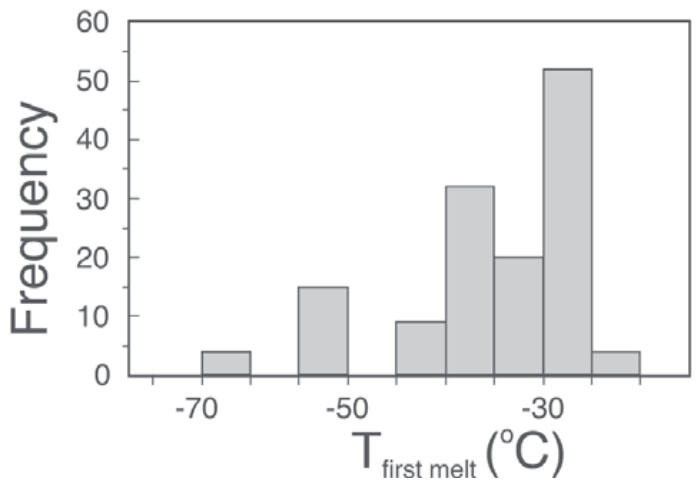

FIG. 6. Thermometric data summarizing temperatures of first melting for fluid inclusions in quartz from altered granite, pegmatite and vein from East Kemptville, Nova Scotia (from Kontak et al. 2001). 


\section{Compositions of evaporate mounds}

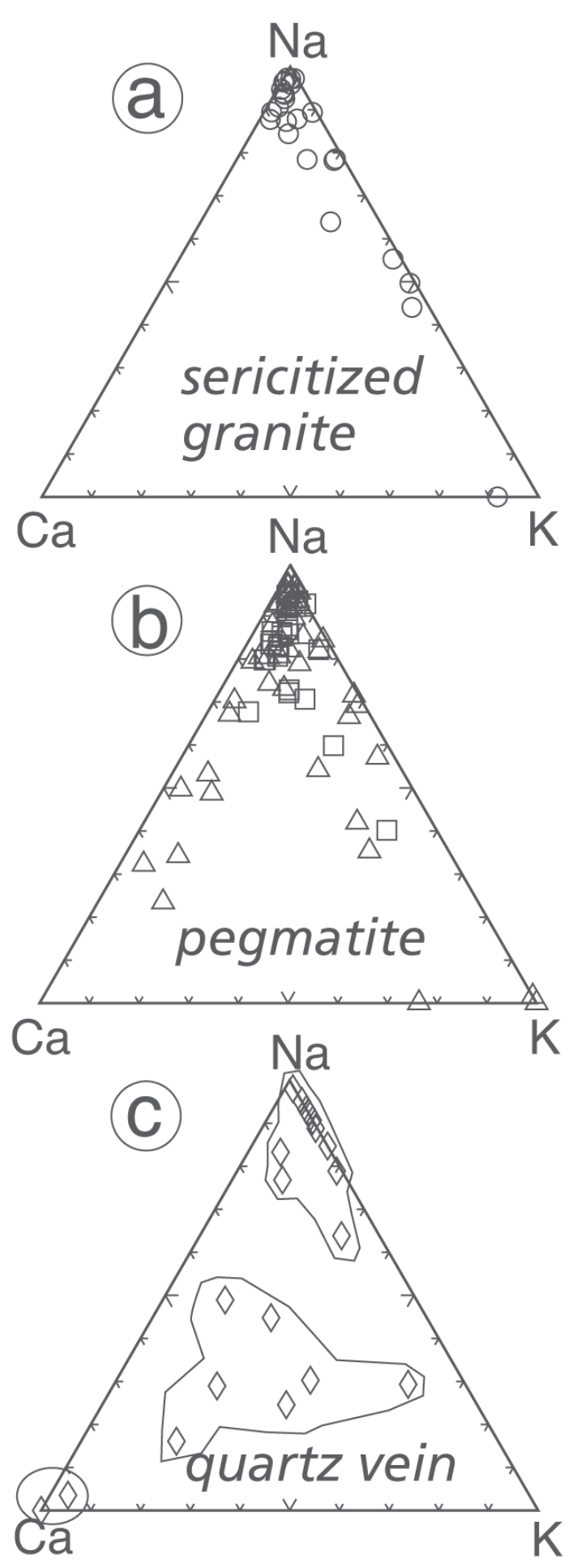

Compositional data have been obtained for evaporate mounds in the quartz megacrysts. The results are somewhat similar to those observed at East Kemptville, with high concentrations of $\mathrm{Na}, \mathrm{K}, \mathrm{Fe}$, and $\mathrm{Mn} ; \mathrm{Mg}$ is present in trace to minor amounts. Mound shapes are also similar to those of East Kemptville, with both the regular, cube-like habit of the $\mathrm{Na}$ - and $\mathrm{K}$-rich mounds and more massive form of those enriched in Fe, Mn and $\mathrm{Mg}$ (inset in Fig. 10a). In the Na-K-Ca plot (Fig. 10a), the data are concentrated along the $\mathrm{Na}-\mathrm{K}$ limb and $\mathrm{Na}-$ rich part of the $\mathrm{Na}-\mathrm{Ca}$ limb, whereas there $\mathrm{Ca}$ is depleted in the mounds (Figs. 10a, c, e). In other plots, it appears that both $\mathrm{Fe}$ and $\mathrm{Mn}$ are associated with $\mathrm{Na}$ rather than $\mathrm{K}$ (Figs. 10b, d), and $\mathrm{Na}, \mathrm{Fe}$ and $\mathrm{Mn}$ are related (Fig. 10f). The results clearly indicate a complex, multi-component fluid with several distinct sub-groupings of the data (i.e., $\mathrm{Na}-\mathrm{Mn}-\mathrm{Fe}$ fluid versus $\mathrm{Na}-\mathrm{K}$ fluid).

\section{Comparison of decrepitate and thermometric data}

The analyses of the mounds confirm that the low $\mathrm{T}_{\mathrm{fm}}$ values indicate the presence of significant $\mathrm{Fe}$ and $\mathrm{Mn}$, rare $\mathrm{Ca}$, and minor $\mathrm{Mg}$ in the fluid inclusions. In addition, the analyses suggest several distinct compositions of fluid that could not be discerned solely on the basis of thermometric results. The presence of a low-salinity fluid is also manifest by areas of evacuated inclusions lacking mounds.

\section{Discussion}

There are several rather diverse aspects of this study that are worthy of discussion. These are addressed separately below. The protocol and validity of the technique, the applications to fluid-inclusion studies in general, and the implications for fluid:rock interaction in granitic environments specifically are discussed in turn.

\section{Validity of technique and application} to fluid-inclusion studies

The decrepitate technique that was pioneered by previous investigators has not been adopted as a routine procedure in fluid-inclusion studies despite the relative simplicity of the technique and the wealth of informa-

FIG. 7. Plots showing $\mathrm{Ca}-\mathrm{Na}-\mathrm{K}$ proportions of decrepitate mounds in (a) altered granite, (b) pegmatite and (c) vein quartz from East Kemptville tin - base-metal deposit, Nova Scotia. Note that in the sample of quartz vein, three populations of mounds are indicated. 

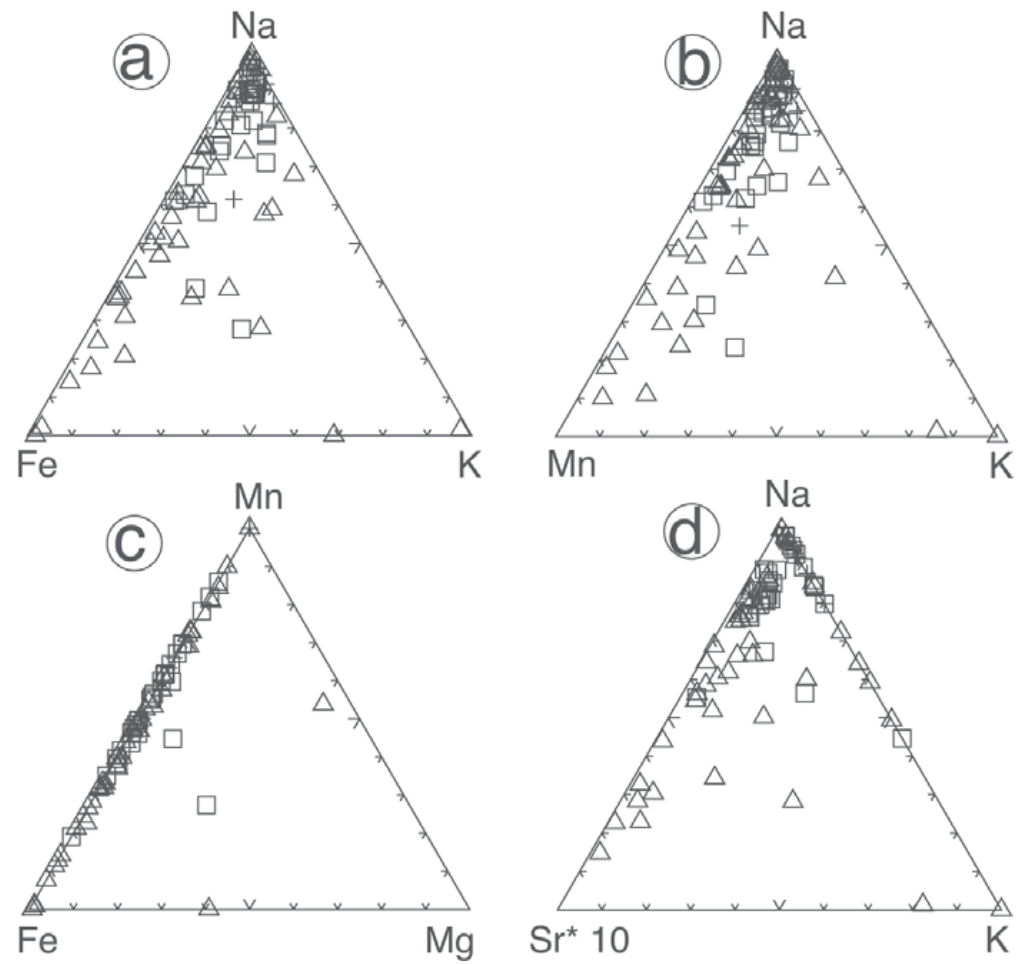

FIG. 8. Plots showing compositions of decrepitate mounds for quartz from altered granite, pegmatite and sulfide vein,East Kemptville, Nova Scotia. (a) Fe-Na-K plot, (b) Mn$\mathrm{Na}-\mathrm{K}$ plot, (c) Fe-Mn-Mg plot, and (d) Sr*10-Na-K plot. Symbols as in Figure 7.

tion that it can provide. There is no question that the method is not without analytical challenges, as discussed and addressed in some detail by Haynes et al. (1988) and briefly raised more recently Roedder \& Bodnar (1997). Whereas most of the analytical details and protocol were the focus of Haynes et al., the concern of Roedder \& Bodnar is that there must be some fractionation of components between the nebulizate and evaporate during the decrepitation procedure. Although this aspect remains an unknown, it is the ratios of the solutes that are examined rather than absolute concentrations. The focus on ratios should minimize the importance of this factor.

More generally, it is noted that in recent reviews of fluid-inclusion procedures and applications, evaporate mounds are given little or no attention compared to a wide variety of other techniques (e.g., Boiron \& Dubessy 1994). Whereas more quantitative information may be obtained with other analytical techniques [e.g., Anderson (2003) for review], it is emphasized that the decrepitate method has merit and can be applied to fluid inclusions in a variety of settings, as has been amply demonstrated by many investigators (e.g., Haynes \&
Kesler 1987, Halter et al. 1998, Savard \& Chi 1998, Kontak et al. 2001). In addition, the foregoing presentation of data from a variety of granite-related settings has shown how this work can be integrated and, in fact, complements standard thermometric work. Thus, what is emphasized here is the relative ease of the technique and the wealth of information that is accessible in a relatively rapid and cost-effective manner.

The studies reported herein are specifically related to granitic environments. As noted in the introduction, however, this technique can easily be applied to a wide range of settings and, based on the writer's experience, a variety of minerals including silicates, sulfides, carbonates and oxides. Although the use of ICP atomic emission spectroscopy has been used to decrepitate mounds, the author is unaware of an application of the more common laser-ablation ICP-MS technique (Sylvester 2001), even though this method is used for in situ analysis of fluid inclusions (Audétat et al. 1998, Anderson 2003). Application of the laser-ablation ICPMS technique should be feasible and would provide a more complete list of elements with, of course, information on abundances of the minor and trace elements. 
Implications for fluid: rock interaction and mineral potential in granitic environments

The results from the three studies discussed above have some fundamental similarities that may, therefore, have implications for fluid : rock interaction within granitic environments. The first observation is that in all cases, there is a tendency for fluids to concentrate on the $\mathrm{K}-\mathrm{Na}$ limb of the $\mathrm{Ca}-\mathrm{Na}-\mathrm{K}$ diagram, with one sole exception (PCG-99-21 in Fig. 5b). This enrichment of $\mathrm{K}$ may be linked to experimental studies, which have demonstrated that as temperature declines, the $\mathrm{K} / \mathrm{Na}$ ratio of the fluid also declines in cases involving fluid alkali feldspar interaction (Orville 1963, Lagache \& Weisbrod 1977). Thus, for the case studies herein, the
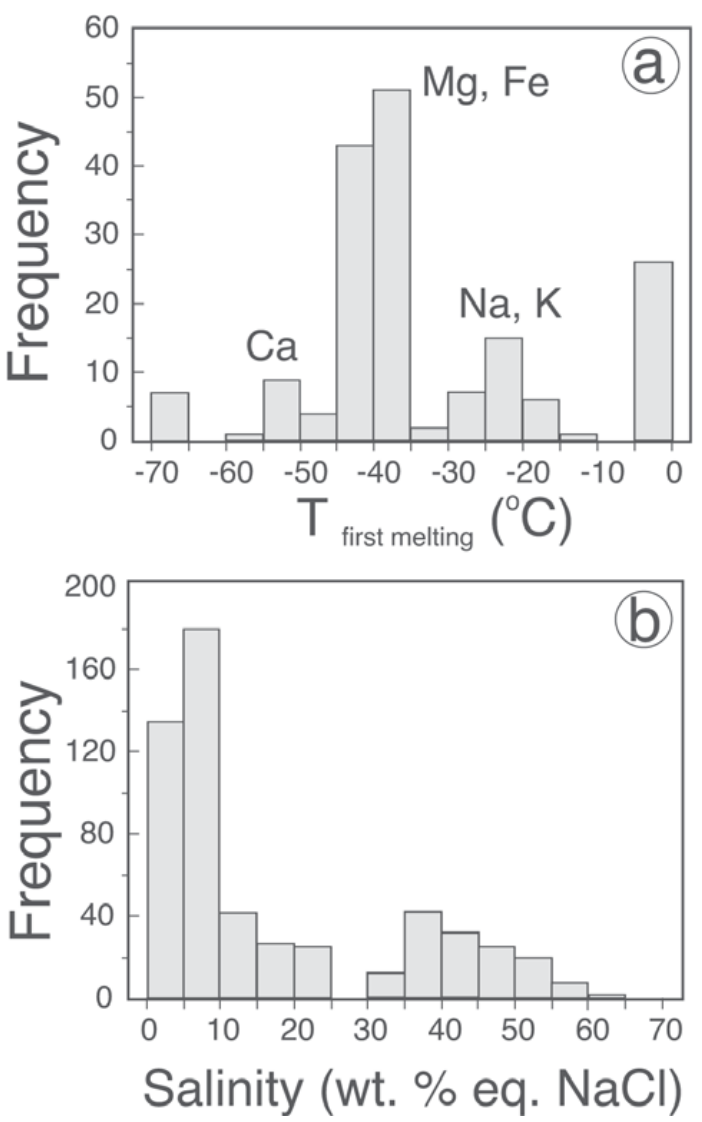

FIG. 9. Histogram plots of thermometric data for fluid inclusions hosted in quartz megacrysts, San Rafael granite, southeastern Peru (from Kontak \& Clark 2002). (a) Temperatures of first melting. The chloride complexes (e.g., $\mathrm{CaCl}_{2}$, Oakes et al. 1990) most likely to be responsible for the eutectic temperatures are indicated (see text for discussion). (b) Salinity, expressed as wt. \% equiv. $\mathrm{NaCl}$, for fluid inclusions. decrepitate data may record the early formation of relatively K-rich fluids and gradual change over time to a more Na-rich fluid as temperature decreases. Relevant to this, therefore, is the fact that sample PCG-99-21a from Peggys Cove, a coarse quartz - K-feldspar - tourmaline - muscovite pocket of an aplite-pegmatite sheet, represents a late-stage product in terms of paragenetic evolution. As such, a fluid generated in this system would be expected to have a low $\mathrm{K} / \mathrm{Na}$ ratio, which it does (Fig. 5b). In a similar manner, the paragenetically late-stage quartz vein at East Kemptville is deficient in $\mathrm{K}$ relative to the higher-temperature, earlier-crystallized pegmatite and altered granite (Fig. 7). Given the secondary nature of all the fluid inclusions in the quartz megacrysts at San Rafael, it is more difficult to interpret the data.

The second observation noted is that there is a distinct association of $\mathrm{Fe}$ and $\mathrm{Mg}$ with $\mathrm{Na}$ enrichment and a distinct lack of such a correlation with $\mathrm{K}$ for the decrepitates from East Kemptville and San Rafael. Assuming that the enrichment of the fluid records an evolution of the magmatic system with time, then the $\mathrm{Fe}$ and $\mathrm{Mn}$ enrichment is related to the same process and explains why there is a decoupling of $\mathrm{K}$ from these elements.

A third observation is that $\mathrm{Ca}$ appears to be coupled with $\mathrm{Na}$, but, like $\mathrm{Fe}$ and $\mathrm{Mn}$, decoupled from $\mathrm{K}$. The best example of this is found in the Peggys Cove samples, where a distinct Ca-rich fluid is recognized from thermometric measurements (i.e., fluid III in Fig. $4 b)$. In this case, an exotic, non-magmatic source within the country rock has been suggested for the $\mathrm{Ca}$ (Kontak et al. 2002), which is consistent with the inferred latestage paragenesis of this fluid. The general lack of $\mathrm{Ca}$ enrichment for the other two areas, East Kemptville and San Rafael, is consistent with other data suggesting that these systems were not infiltrated by an extraneous fluid that had equilibrated with the surrounding metasedimentary country-rock.

A final observation is that of the three systems examined, two are mineralized and one is barren. Although this is not a sufficiently large enough database from which to draw conclusions, the fact remains that the fluid compositions from the two mineralized systems are highly enriched in $\mathrm{Fe}$ and $\mathrm{Mn}$. Detailed studies of fluid inclusions from $\mathrm{Sn}-$ and $\mathrm{Cu}-\mathrm{Au}$ mineralized systems (e.g., Heinrich et al. 1992, 1999, Rankin et al. 1992, Audétat et al. 1998) have shown that these metals, among many others, are enriched along with $\mathrm{Na}$ and $\mathrm{K}$. Thus, at first hand it appears that perhaps the decrepitate method offers a rapid, easy method to quickly assess samples for their affinity to mineralization and also for subsequent work using laser-ablation ICP-MS and PIXE analyses employed in the aforementioned studies.

\section{Conclusions}

The analysis of evaporate mounds is a relatively easy and rapid method for the acquisition of compositional 

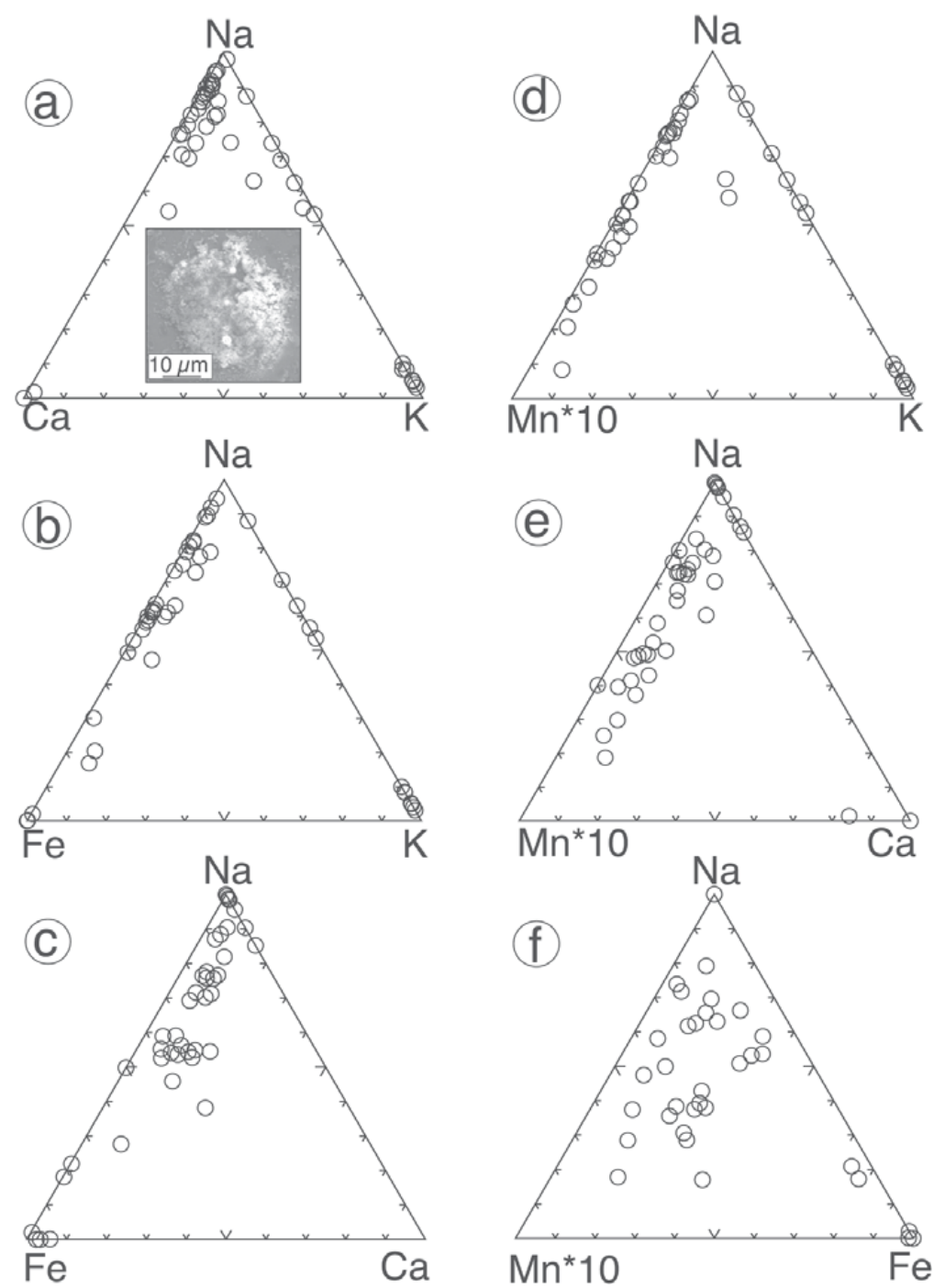

FIG. 10. Plots showing compositions of decrepitate mounds from quartz megacrysts in San Rafael granite, southeastern Peru. (a) Ca-Na-K plot with inset back-scattered electron image of mound enriched in $\mathrm{Na}-\mathrm{K}-\mathrm{Fe}-\mathrm{Mn}$. (b) $\mathrm{Fe}-\mathrm{Na}-\mathrm{K}$ plot. (c) $\mathrm{Fe}-\mathrm{Na}-\mathrm{Ca}$ plot. (d) Mn*10-Na-K plot. (e) Mn*10-Na-Ca plot. (f) Mn*10-Na-Fe plot.

information from fluid inclusions. Although the method was first employed nearly thirty years ago (Eadington 1974) and Haynes et al. (1988) provided a critical assessment of the technique, this relatively easy method of acquiring semiquantitative compositional data on fluid inclusions has not become widely applied. The application of the technique to three granitic environments has shown the following: (1) mound composition is consistent with and complements compositional information inferred from routine thermometric mea- surements. (2) Compositional information not obtained from thermometry is easily obtained (e.g., Mn, Fe contents). In some cases, the presence of minor elements (i.e., Sr, Ba, P at East Kemptville) is also indicated. (3) Cationic proportions (e.g., $\mathrm{Ca}-\mathrm{Na}-\mathrm{K})$ of the important major and minor elements within most inclusions provide important information regarding fluid : rock interaction and fluid evolution within the granitic environment. (4) Specifically within granitic environments, the method may provide a valuable means of distin- 
guishing between potentially mineralized versus barren environments.

The integration of information from decrepitate analysis with standard thermometric studies provides a rapid and effective means of elucidating the cation proportions in fluid inclusions, which has important implications in terms of the fluid reservoirs and fluid: rock interaction. Such work should become a standard part of fluid-inclusion studies.

\section{ACKNOWLEDGEMENTS}

It was the intent of the writer that by presenting the results of this research at PACROFI 2002 in Halifax, Nova Scotia, it might reveal to others the value of this technique. The response of those who attended this meeting and who provided constructive criticism encouraged the writing of this paper. To the PACROFI 2002 delegates, a sincere appreciation. Work at the various localities reported here has been done in collaboration with a number of people, in particular A.H. Clark, W. Halter, A.E. Williams-Jones, and J. Dostal. Work in Nova Scotia was supported by the Nova Scotia Department of Natural Resources, whereas work at San Rafael was supported by an NSERC grant to A.H. Clark, Queen's University, Kingston, Ontario. Reviews of the manuscript by A. Anderson, T. Lowenstein and G. Chi are also acknowledged, as is the editorial handling of the paper.

\section{REFERENCES}

Anderson, A. (2003): Electron, nuclear and X-ray probe microanalysis of fluid inclusions. In Fluid Inclusions: Analysis and Interpretation (I. Samson, A. Anderson \& D. Marshall, eds.). Mineral. Assoc. Can., Short Course Vol. 32 ,

AudÉtAT, A., GÜNTHER, D. \& HeInRICH, C.A. (1998): Formation of a magmatic-hydrothermal ore deposit: insights with LA-ICP-MS analysis of fluid inclusions. Science $\mathbf{2 7 9}$, 2091-2094.

BODNAR, R.J. \& VITYK, M.O. (1994): Interpretation of microthermometric data for $\mathrm{H}_{2} \mathrm{O}-\mathrm{NaCl}$ fluid inclusions. In Fluid Inclusions in Minerals: Methods and Applications (B. De Vivo \& M.L. Frezzotti, eds.). Short Course of the IMA Working group on Inclusions in Minerals (Pontignano-Siena, Italy), 117-130.

BoIron, M.-C. \& Dubessy, J. (1994): Determination of fluid inclusion compositions: microanalytical techniques. In Fluid Inclusions in Minerals: Methods and Applications (B. De Vivo \& M.L. Frezzotti, eds.). Short Course of the IMA Working group on Inclusions in Minerals (Pontignano-Siena, Italy), 45-71.

BorisenKo, A.S. (1977): Cryometric technique applied to studies of the saline composition of solution in gaseous fluid inclusion in minerals. Akad. Nauk SSSR, Geol. Geophys., 16-27 (in Russ.).
Carruzzo, S., KontaK, D.J. \& Clarke, D.B. (2000): Granitehosted mineral deposits of the New Ross area, South Mountain Batholith, Nova Scotia, Canada: $\mathrm{P}, \mathrm{T}$ and $X$ constraints of fluids using fluid inclusion thermometry and decrepitate analysis. Trans. R. Soc. Edinburgh, Earth Sci. 91, 303- 319.

Chryssoulis, S. \& WiLkinson, N. (1983): High silver content of fluid inclusions in quartz from Guadalcaza Granite, San Luis Potosi, Mexico: a contribution to ore-genesis theory. Econ. Geol. 78, 302-318.

Clark, A.H., Chen, Yanshao, Grant, J.W., Kontak, D.J., Wasteneys, H.A., Sandeman, H.A., Farrar, E. \& ARCHIBALD, D.A. (2000): Delayed inception of ore deposition in major lithophile-metal vein systems: the San Rafael tin and Pasto Bueno tungsten deposits, Peru. Geol. Soc. Am., Program Abstr. 32(7), 279.

CRAWFORD, M.L. (1981): Phase equilibria in aqueous fluid inclusions. In Fluid Inclusions: Applications to Petrology (L.S. Hollister \& M.L. Crawford, eds.). Mineral. Assoc. Can., Short Course Handbook 6, 75-100.

Dostal, J. \& ChATTERJEe, A.K. (1995): Origin of topaz-bearing and related peraluminous granites of the late Devonian Davis Lake pluton, Nova Scotia, Canada. Chem. Geol. 123, 67-88.

Dubois, M. \& Marignac, C. (1997): The $\mathrm{H}_{2} \mathrm{O}-\mathrm{NaCl}-\mathrm{MgCl}_{2}$ ternary phase diagram with special application to fluid inclusion studies. Econ. Geol. 92, 114-119.

EADINGTON, P.J. (1974): Microprobe analysis of the non-volatile constituents of fluid inclusions. Neues Jahrb Mineral., Monatsh., 518-525.

GoldsteIn, R.H. \& REYNolds, T.J. (1994): Systematics of fluid inclusions in diagenetic minerals. SEPM (Soc. for Sedimentary Geology), Short Course 31.

HALL, D.L., STERnER, S.M. \& BodnAR, R.J. (1988): Freezing point depression of $\mathrm{NaCl}-\mathrm{KCl}-\mathrm{H}_{2} \mathrm{O}$ solutions. Econ. Geol. 83, 197-202.

Halter, W.E., Williams-Jones, A.E. \& KontaK, D.J. (1996): The role of greisenization in cassiterite precipitation at the East Kemptville tin deposit, Nova Scotia. Econ. Geol. 91, 368-385.

\& (1998): Origin and evolution of the greisenizing fluid at the East Kemptville tin deposit, Nova Scotia, Canada. Econ. Geol. 93, 1026-1051.

HAynes, F.M. (1985): Determination of fluid inclusion composition by sequential freezing. Econ. Geol. 80, 1436-1439.

\& KESLER, S.E. (1987): Chemical evolution of brines during Mississippi Valley-type mineralization: evidence from east Tennessee and Pine Point. Econ. Geol. 82, 5371.

STERner, S.M. \& Bodnar, R.J. (1988): Synthetic fluid inclusions in natural quartz. IV. Chemical analyses of 
fluid inclusions by SEM/EDA: evaluation and method. Geochim. Cosmochim. Acta 52, 969-977.

Heinrich, C.A., Günther, D., Audétat, A., Ulrich, T. \& FRISCHKNECHT, R. (1999): Metal fractionation between magmatic brine and vapor, determined by microanalysis of fluid inclusions. Geology 27, 755-758.

Ryan, C.G., Mernagh, T.P. \& Eadington, P.G. (1992):Segregation of ore metals between magmatic brine and vapor: a fluid inclusion study using PIXE microanalysis. Econ. Geol. 87, 1566-1583.

KonTAK, D.J. (1994): Geological and geochemical studies of alteration processes in a fluorine-rich environment: the East Kemptville $\mathrm{Sn}-(\mathrm{Zn}-\mathrm{Cu}-\mathrm{Ag})$ deposit, Yarmouth County, Nova Scotia, Canada. In Alteration and Alteration Processes Associated with Ore-Forming Systems (D.R. Lentz, ed.). Geol. Assoc. Can., Short Course Notes 11, 261-314.

ANSDELL, K. \& ARChIBALD, D.A. (1999): New constraints on the age and origin of the Dunbrack $\mathrm{Pb}-\mathrm{Cu}-\mathrm{Zn}-$ $\mathrm{Ag}$ deposit, Musquodoboit Batholith, southern Nova Scotia. Atlantic Geology 35, 19-42.

Dostal, J., Halter, W., Martin, R. \& WiLLIAMS-Jones, A.E. (2001): The nature and origin of pegmatites in a fluorine-rich leucogranite, East Kemptville tin deposit, Nova Scotia, Canada. Trans. R. Soc. Edinburgh: Earth Sci. 92, 173-2000.

\& Clark, A.H. (2002): Genesis of the giant, bonanza San Rafael lode tin deposit, Peru: origin and significance of pervasive alteration. Econ. Geol. 97, 1741-1777.

\& FARRAR, E. (1984):The influences of fluid and rock compositions, and tectono-thermal processes on Al-Si distribution in alkali feldspars in granitoid rocks, S.E. Peru. Bull. Minéral. 107, 387-400.

Dostal, J., Kyser, T.K. \& Archibald, D.A. (2002): A petrological, geochemical, isotopic and fluid inclusion study of 370 Ma pegmatite-aplite sheets, Peggys Cove, Nova Scotia, Canada. Can. Mineral. 40, 1249-1286.

\& KYSER, T.K. (2001): Preliminary fluid inclusion and oxygen isotope studies of Flinstone Rock (NTS 11E/ 13) silica-clay deposit, Yarmouth County, Nova Scotia. In Mines and Minerals Branch Report of Activities 2000 (D.R. MacDonald, ed.). Nova Scotia Dep. Nat. Resources, Rep. 2001-1, 37-48.

\&

(2002): Nature and origin of Cornwalltype clay mineralization in southwest Nova Scotia, Canada: the Black Bull Resources Inc. Yarmouth silica-kaolinite deposit. Geol. Assoc. Can. - Mineral. Assoc. Can., Program Abstr. 27, 63.

LAGACHE, M. \& WeIsBrod, A. (1977): The system: two alkali feldspars- $\mathrm{KCl}-\mathrm{NaCl}-\mathrm{H}_{2} \mathrm{O}$ at moderate to high tempera- tures and low pressures. Contrib. Mineral. Petrol. 62, 77 101.

MacDonald, M.A. \& Horne, R.J. (1988): Petrology of the zoned, peraluminous Halifax Pluton, south-central Nova Scotia. Maritime Sediments \& Atlantic Geology 24, 33-45.

OAKES, C.S., BodnaR, R.J. \& Simonson, J.M. (1990): The system $\mathrm{NaCl}-\mathrm{CaCl}_{2}-\mathrm{H}_{2} \mathrm{O}$. I. The ice liquidus at 1 atm total pressure. Geochim. Cosmochim. Acta 54, 603-610.

ORVILLE, P.M. (1963): Alkali ion exchange between vapor and feldspar phases. Am. J. Sci. 261, 201-237.

Palma, V. \& Clark, A.H. (1982): The San Rafael tin-copper lode system, Puno, SE Peru: a Cornwall-type deposit in the central Andean tin belt. Geol. Assoc. Can. - Mineral. Assoc. Can., Program Abstr. 7, 71.

PALMER, D.A.S. \& Williams-Jones, A. (1996): Genesis of the carbonatite-hosted fluorite deposit at Amba Dongar, India: evidence from fluid inclusions, stable isotopes and whole rock-mineral geochemistry. Econ. Geol. 91, 934-950.

Rankin, A.H., Ramsey, M.H., Coles, B., Van Langevelde, F. \& THOMAS, C.R. (1992): The composition of hypersaline, iron-rich granitic fluids based on laser-ICP and synchrotron-XRF microprobe analysis of individual fluid inclusions in topaz, Mole granite, eastern Australia. Geochim. Cosmochim. Acta 56, 67-79.

Roedder, E. (1984): Fluid inclusions. Rev. Mineral. 12

\& BODNAR, R.J. (1997): Fluid inclusion studies of hydrothermal ore deposits. In Geochemistry of Hydrothermal Ore Deposits (H.L. Barnes, ed.). John Wiley \& Sons, New York, N.Y. (657-697).

SAMSON, I.M. \& WALKER, R.T. (2000): Cryogenic raman spectroscopic studies in the system $\mathrm{NaCl}-\mathrm{CaCl}_{2}-\mathrm{H}_{2} \mathrm{O}$ and implications for low-temperature phase behavior in aqueous fluid inclusions. Can. Mineral. 38, 35-43.

SAVArD, M.M. \& ChI, Guoxiang (1998): Cation study of fluid inclusion decrepitates in the Jubilee and Gays River (Canada) $\mathrm{Zn}-\mathrm{Pb}$ deposits - characterization of ore-forming brines. Econ. Geol. 93, 920-931.

SYLVESTER, P., ed. (2001): Laser-ablation - ICPMS in the Earth Sciences. Mineral. Assoc. Can., Short Course Ser. 29.

VAnko, D.A., Bodnar, R. \& Sterner, S.M. (1988): Synthetic fluid inclusions. VIII. Vapor-saturated halite solubility in part of the system $\mathrm{NaCl}-\mathrm{CaCl}_{2}-\mathrm{H}_{2} \mathrm{O}$ with application to fluid inclusions from oceanic hydrothermal systems. Geochim. Cosmochim. Acta 52, 2451-2456.

Received December 1, 2002, revised manuscript accepted January 3, 2004. 